\title{
Effects of temperature increase on the grazing of planktonic bacteria by biofilm-dwelling consumers
}

\author{
Marcel Kathol, Helge Norf, Hartmut Arndt, Markus Weitere* \\ Department of General Ecology and Limnology, Zoological Institute, University of Cologne, 50931 Cologne, Germany
}

\begin{abstract}
Biofilms, the complex microbial communities associated with surfaces, can play an important role in the flux of matter in running waters. In addition to bacteria and algae, heterotrophic protists and small metazoans can also occur in high abundances in biofilms. By grazing on planktonic prey, biofilm-dwelling grazers can act as a trophic link between planktonic and benthic food webs, parallel to filter-feeding benthic macroinvertebrates. Here we introduce a flow cell method for the quantification of grazing rates of semi-natural biofilms on suspended bacteria, parallel to microscopic biofilm community analysis. This technique was used to measure the temperature response of the grazing rates of complex biofilm communities (established in a bypass system to the River Rhine, Germany) on planktonic bacteria. Results showed that $14 \mathrm{~d}$ old biofilms (dominated by ciliates) clear planktonic bacteria at rates between 29 (in winter) and $99 \mathrm{l} \mathrm{m}^{-2}$ biofilm d $\mathrm{d}^{-1}$ (in summer) at ambient temperature. These rates increased with test temperature, even at temperatures $\left(>30^{\circ} \mathrm{C}\right)$ at which the grazing rates of filter-feeding macrofauna in moderate climates are negatively influenced. The acclimation temperatures under which the biofilm developed can have a significant effect on community clearance rates, largely due to a temperature effect on the abundance and structure of the grazer community, whereas no indication of an acclimation effect on individual grazing rates could be found. In the function of bentho-pelagic couplers, biofilm-dwelling consumer communities can react to temperature changes substantially faster than macrofaunal filter feeders.
\end{abstract}

KEY WORDS: Biofilms · Ciliates · Protists · Bentho-pelagic coupling $\cdot$ Ingestion rates $\cdot$ Picoplankton · Running waters · Periphyton

Resale or republication not permitted without written consent of the publisher

\section{INTRODUCTION}

Aquatic microorganisms can occur in high densities in association with surfaces (e.g. Hillebrand et al. 2002, Arndt et al. 2003, Hall-Stoodley et al. 2004); such a complex community of bacteria, algae, fungi, heterotrophic protists and small metazoans is termed 'biofilm' (cf. Wetzel 2001). Biofilm-dwelling organisms can contribute greatly to the material flux in an aquatic ecosystem, e.g. to algal primary production (e.g. Mulholland et al. 1994) or to bacterial turnover of organic matter (e.g. Fischer \& Pusch 2001). Phagotrophic protists can occur in high densities of between $10^{2}$ and $>10^{5}$ cells $\mathrm{cm}^{-2}$ in biofilms (Franco et al. 1998, Arndt et al. 2003, Esser 2006), and recent studies have highlighted their role in the control of bacterial biofilms (Huws et al. 2005, Weitere et al. 2005a). However, a closer look at the composition of biofilmdwelling consumer communities reveals that a large proportion (often $>>50 \%$ ) is composed of groups that feed on plankton rather than on surface-associated prey (Arndt et al. 2003, Weitere et al. 2003, Parry 2004, Esser 2006). These findings have stimulated considerations that biofilm-associated phagotrophic protists might play a significant role in controlling plankton and thus in linking planktonic and benthic food webs (Weitere et al. 2003). Dominant suspension-feeding groups that occur in biofilms include the predominantly picophagous peritrich ciliates and the predominantly nano- and microphagous heterotrich ciliate genus Stentor (Fenchel 1980, Franco et al. 1998, Kim et al. 2007). 
The important role of bentho-pelagic coupling in the material flux in shallow waters, particularly in streams and rivers, has been highlighted by an increasing number of studies (e.g. Welker \& Walz 1998, Caraco et al. 2006). Up to now, components of the macrofauna (mostly bivalves) were considered to be primarily responsible for this key function. However, considering the high abundances of biofilm-associated ciliates and small metazoans (see above) as well as their potentially high grazing rates (e.g. Sanders et al. 1989, Hadas et al. 1998, Simek et al. 2000, Parry 2004), it seems likely that biofilms could be a significant consumer of plankton. Losses of different plankton groups (e.g. bacteria, algae and heterotrophic protists) to biofilms have been experimentally demonstrated by Weitere et al. (2003). However, quantitative studies on the grazing rates of well-characterized, mixed biofilm communities are few. Furthermore, the consideration of biofilm communities in the context of plankton consumption brings up new functional aspects, as the communities of unicellular organisms show larger dynamics and can react substantially faster to variations in the environmental conditions than filter-feeding macrofauna.

The understanding of ecosystem and organism responses to changing environmental conditions is becoming increasingly important in the context of climate warming. Warming has direct and indirect effects on organisms and ecosystems at different scales. For example, climate change could have a strong impact on interaction strength and feeding rates of organisms (Sanford 1999, Winder \& Schindler 2004). In order to assess such consequences, it is important to consider temperature-sensitive key interactions that contribute significantly to ecosystem functioning (cf. Sanford 1999). Recent studies have identified benthopelagic coupling as a leverage point through which temperature changes can generate rapid changes in the composition of planktonic communities due to differential development of the grazing rates of benthic macrograzers (such as bivalves) and differential growth of planktonic communities due to differential development between the grazing rates of benthic macrograzers (such as bivalves) and the growth rates of their planktonic prey (Viergutz et al. 2007, Weitere et al. 2008). However, it is still unknown whether or not community grazing rates of biofilm-dwelling grazers respond in a similar manner to warming as macrofaunal grazing rates. It seems likely that microbial biofilm communities can respond more quickly to changing temperatures because they contain a large pool of grazers with different thermal optima and can thus rapidly shift in their relative importance (due to their short generation times and high densities) with changes in abiotic and/or biotic conditions. Such community shifts might also enable biofilm communities to keep high grazing rates at high temperatures $\left(>25^{\circ} \mathrm{C}\right)$ at which macrofaunal grazing rates are negatively affected (Viergutz et al. 2007).

Here, we introduce a new tool that allows the measurement of grazing rates of semi-natural biofilm communities on the plankton in parallel to the taxonomic characterization of the biofilm communities. This system is based on flow cells used as a bypass to natural waters (Norf et al. 2007). We measured the grazing rates of biofilm communities that developed in the river bypass system on planktonic bacteria under different seasonal conditions and different manipulations of the acclimation temperature. Hypotheses tested were: (1) plankton-consuming groups form a large part of naturally established, biofilm-dwelling consumer communities, (2) their community grazing rates on planktonic bacteria increase with increasing temperature (even above the thermal optimum of macrofaunal filter feeders), and (3) acclimation temperature influences the abundance and composition of biofilmdwelling grazers (cf. Norf et al. 2007) and thus their function as plankton consumers.

\section{MATERIALS AND METHODS}

Study site and experimental set-up. All experiments were conducted with natural water from the river Rhine aboard the 'Ecological Rhine Station' of the University of Cologne. The Ecological Rhine Station is a boat facility located in Cologne, Germany (Rhine $685.5 \mathrm{~km}$ ) that possesses several laboratories equipped with pump systems for experimental assemblies that use fresh river water. With a total length of $1326 \mathrm{~km}$, the Rhine is one of the largest rivers in central Europe. Due to its artificial straightening for shipping purposes, it is characterized by a high mean velocity $\left(\sim 1.5 \mathrm{~m} \mathrm{~s}^{-1}\right.$ at Cologne). Consequently, the river is poor in habitat diversity and in macrophytes, and the river bed consists of gravel and stones suitable for colonization by biofilms. Another consequence of the high velocity is the strong turbulence, which leads to a well-mixed water body with homogenous vertical distribution of chemo-physical parameters as well as suspended particles. The Rhine carries a well-established planktonic community, which is predominantly composed of unicellular organisms, i.e. bacteria, algae and heterotrophic protists (Weitere et al. 2005b). The vast majority of planktonic bacteria are suspended as single cells (Weitere \& Arndt 2002).

We pumped natural Rhine water through the experimental flow cells (see next section) and allowed biofilms containing complex, semi-natural grazer communities to become established. In the experiments, we manipulated temperature conditions during $14 \mathrm{~d}$ of 
biofilm growth to allow thermal acclimation of the organisms (see next section and Table 1 for acclimation temperatures). The biofilms established under the controlled acclimation conditions were then used to measure grazing rate responses under short-term temperature increases by applying a range of increasing test temperatures during the grazing rate measurements (see next section and Table 1 for test temperatures).

Flow cell experiments. Grazing rates were determined by measuring changes in the abundances of planktonic bacteria flowing over biofilms. The experiments were conducted in flow cell systems as used by Norf et al. (2007). The system consists of 2 inflows and 2 outflows, and has an inner dimension of $4.0 \times 1.9 \times$ $0.5 \mathrm{~cm}$, corresponding to a surface area of $21.1 \mathrm{~cm}^{2}$ and a volume of $3.8 \mathrm{ml}$. One large side is covered with a cover slip to allow for non-destructive taxonomic characterization of the biofilm communities under a microscope.

To assess seasonal variation in both the biofilm structure and the corresponding biofilm function as a sink for planktonic bacteria, 4 experiments were performed: one in early June 2005 (hereafter summer 05), one in October 2005 (autumn 05), one in January 2006 (winter 06) and one in May 2006 (spring 06). The exact dates, as well as the experimental conditions, are summarized in Table 1. Biofilm establishment took place during a colonization phase of $14 \mathrm{~d}$. This time interval was sufficiently long to reach a steady state (near steady state at low temperature in January) in the abundance of biofilm-dwelling ciliates (cf. Norf et al. 2007). Chemically untreated, pre-filtered (300 $\mu \mathrm{m}$ mesh size) Rhine water was pumped through the flow cells at a constant flow rate of $150 \mathrm{ml} \mathrm{h}^{-1}$, which is sufficiently high to support the establishment of a complex, biofilm-dwelling grazer community. Differences in the abundances of planktonic bacteria between inand outflows (which could lead to resource-dependent gradients in grazer abundance within the flow cells) were low at this flow rate. The flow cells were placed in temperature-controlled water baths for the establishment of the biofilms. Constant acclimation temperatures were adjusted to the mean Rhine temperature at the particular time period (semi-monthly averages since 1989), i.e. $19.0,16.7,6.6$ and $13.7^{\circ} \mathrm{C}$ in summer 05, autumn 05, winter 06 and spring 06, respectively. To test the impact of the acclimation temperature at a given setting, additional biofilms were established in summer 05 and winter 06 at a temperature of $6^{\circ} \mathrm{C}$ above the base temperature. Each acclimation treatment was replicated $4 \times(3 \times$ in autumn 05$)$.

After allowing the biofilms to develop for $14 \mathrm{~d}$ at controlled acclimation temperatures, the inflow tubes were replaced with new ones before the grazing experiment started. Five single tubes, which were not connected to flow cells, were also installed for sampling of the inflowing water. Temperature was adjusted to the base acclimation temperature (see above) for all flow cells, and the flow rate was adjusted to $24 \mathrm{ml} \mathrm{h}^{-1}$. At this flow rate, differences in the abundances of planktonic bacteria between inflow and outflow were detectable for all seasons. After $1 \mathrm{~h}$ (during which the water volume was exchanged $6.3 \times$ ), plankton samples were taken from the in- and outflow of the flow cell. Temperature was then set one step higher (see Table 1 for test temperature steps) and sampling was again conducted after an acclimation time of $1 \mathrm{~h}$. This procedure was repeated for the different test temperatures.

Calibration of the method. An important assumption for the presented method is that no other significant losses of planktonic bacteria (e.g. by sedimentation or by adherence to the biofilm) apart from those to biofilm-dwelling consumers occur. The grazing rate should therefore be a linear function of the number of grazers, with the regression line intercepting the origin. This was tested parallel to the October experiment. For this purpose, 4 additional flow cells were prepared in parallel to the 3 regular replicates used for the temperature response experiment. After measuring the grazing rates, all replicates were treated with specific eukaryote inhibitors, i.e. a mixture of $400 \mu \mathrm{g} \mathrm{l}^{-1}$ colchicine and $400 \mu \mathrm{g} \mathrm{l}^{-1}$ cycloheximide (Sherr et al. 1986), for 14 h. A few ciliates remained on the biofilms after this treatment. After quantification of the remaining ciliates, the grazing experiments were repeated at a temperature of $19.7^{\circ} \mathrm{C}$.

In a second, independent calibration experiment, we tested whether or not pure, untreated bacterial biofilms (without the presence of consumers and without the application of inhibitors) alone could lead to a loss of planktonic bacteria, e.g. due to adherence to the sticky biofilm surface. For this purpose, natural (mixed-species) bacterial assemblages from the Rhine were cultivated from $1 \mu \mathrm{l}$ inoculates. After checking that they were grazer-free, 10 of these cultures were mixed together and the bacteria were then introduced into autoclaved flow cell systems. These flow cells were run with particle-free, autoclaved Rhine water for $2 \mathrm{wk}$. After ensuring that bacterial biofilms without grazers were established, the flow cells were connected to untreated Rhine water and loss rates of planktonic bacteria were quantified using the same protocol as that for the regular grazing experiments (see 'Calculation of clearance and ingestion rates').

Quantification of biofilm-dwelling ciliates and rotifers. Potential biofilm-dwelling grazers on plankton (i.e. ciliates and rotifers) were quantified alive at the beginning of the grazing experiments for all replicates. The occurrence of flagellates and amoebas as 
additional potential grazers was routinely checked, but these grazers occurred in much lower biomasses than ciliates and rotifers (see also Weitere et al. 2003). Counting was performed using a Zeiss Axioskop upright microscope equipped with phase contrast and digital video facilities for documentation at magnifications of $50 \times$ to $630 \times$. Approximately 60 ind. (ciliates and rotifers) were recorded in areas of defined sizes which were randomly distributed over the total area of the cover slip. Taxonomic characterization was conducted with the help of specific keys (e.g. Foissner \& Berger 1996). Generally, ciliate classification followed the system of Adl et al. (2005). For the determination of total biovolume, the body size of the ciliates and rotifers were measured and the volume was calculated by assuming specific geometric forms for each taxonomic group (cf. Hillebrand et al. 1999).

Natural biofilm communities. To compare grazer communities within the flow cell experiments, we quantified biofilm-dwelling ciliates and rotifers on natural biofilms of the River Rhine which had grown on the surface of exposed natural basalt rock. For this purpose, basalt tiles (4 replicates in each case) of the size of object slides were exposed in the main flow of the River Rhine at the Ecological Rhine Station (see section 'Study site and experimental set-up') for $3 \mathrm{mo}$, during which time, mature biofilms were established. For community analyses, the biofilms were scraped off the basalt tiles with a glass slide and washed with particlefree (passed through sterile $0.2 \mu \mathrm{m}$ syringe filter) Rhine water. The suspension was then adjusted to a defined water volume of $5 \mathrm{ml}$ and immediately live-counted in subsamples (40 to $80 \mu \mathrm{l}$ ). Quantification and taxonomic classification were performed in the same manner as described in the previous section. Analyses of 3 mo old natural biofilms were performed $4 \times$ in 2007 , covering the same seasons as in the flow cell experiments in 2005-06. The sampling dates were 20 April 2007 (spring 07), 21 June 2007 (summer 07), 22 October 2007 (autumn 07) and 20 December 2007 (winter 07).

Analysis of planktonic bacteria. For the quantification of planktonic bacteria at the in- and outflow of the flow cells, $5 \mathrm{ml}$ of each sample were fixed with ice-cold $4 \%$ glutaraldehyde solution (final concentration: $2 \%$ ) immediately after sampling. Within $24 \mathrm{~h}, 3$ to $5 \mathrm{ml}$ (depending on the concentration of seston load in the sample) of the glutaraldehyde-fixed samples were stained with DAPI (Porter \& Feig 1980) at a final DAPI concentration of $10 \mu \mathrm{g} \mathrm{ml}^{-1}$ and filtered onto black polycarbonate membrane filters $(0.2 \mu \mathrm{m}$, WhatmanNuclepore). The stained filters were kept frozen at $-20^{\circ} \mathrm{C}$ until the bacteria were quantified under an epi-

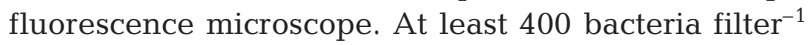
were counted in defined areas randomly distributed over the total filter area. For estimation of the size spectrum, the cell dimensions of $\sim 150$ bacteria filter $^{-1}$ were measured with the help of a calibrated ocular micrometer at highest magnification (1000×) and assigned to 21 size classes, because exact measurement of small bacteria by light microscopy is not possible.

Calculation of clearance and ingestion rates. Based on the abundances of the planktonic bacteria in the inflow $\left(N_{0}\right.$, cells $\left.\mathrm{ml}^{-1}\right)$ and the outflow $\left(N_{1}\right.$, cells $\left.\mathrm{ml}^{-1}\right)$ and after the residence time of the river water in the flow cells $(t, 0.1583 \mathrm{~h})$, the rate of change in planktonic bacterial abundance $\left(r, \mathrm{~h}^{-1}\right)$ was calculated by assuming exponential changes as follows:

$$
r=\left(\ln N_{1}-\ln N_{0}\right) / t
$$

Mortality rate $(r \times(-1))$ was considered as the grazing rate, because growth of the plankton does not play a significant role due to the short residence time of the water in the flow cells. This grazing rate, multiplied by the volume of the flow cell $(V, 3800 \mu \mathrm{l})$ and divided by the total abundances of ciliates and rotifers $\left(N_{\text {biofilm }}\right.$ ind. (flow cell) $\left.)^{-1}\right)$, gives the clearance rate $\left(C R, \mu l\right.$ ind. ${ }^{-1}$ $\mathrm{h}^{-1}$ ) per individual biofilm-dwelling consumer:

$$
C R=r \times V / N_{\text {biofilm }} \times(-1)
$$

Ingestion rate $\left(I R\right.$, cells ind.$\left.^{-1} \mathrm{~h}^{-1}\right)$ per individual grazer was calculated by multiplying the $C R$ by the abundance of bacteria $\left(N_{0}\right.$, cells $\left.\mu l^{-1}\right)$ as:

$$
I R=C R \times N_{0}
$$

The $C R$ and $I R$ were also calculated in relation to the biofilm surface area to permit comparisons between the different treatments and of seasonal variations among the experiments.

To get the clearance rate per surface biofilm $(C R$, $\left.1 \mathrm{~m}^{-2} \mathrm{~d}^{-1}\right)$, the mortality rate was multiplied by the volume of the flow cell $(V, 0.0038 \mathrm{l})$ and by $24 \mathrm{~h}$, then divided by the total inner surface area of the flow cell $\left(F, 0.00211 \mathrm{~m}^{2}\right)$ :

$$
C R=r \times V \times 24 \times(-1) / F
$$

The ingestion rate per surface biofilm $\left(I R\right.$, cells $\left.\mathrm{m}^{-2} \mathrm{~d}^{-1}\right)$ was calculated in the same manner as described above (see Eq. (3)).

Statistical analysis. Statistical analyses were performed using SPSS 12.0 for Windows. The dependence of grazer biovolume and abundance on the different acclimation treatments (for the summer and winter experiments) was tested separately for each experiment using Student's $t$-test. The dependence of clearance rates on the acclimation conditions was tested using repeated measures ANOVAs with temperature as the within-subject variable and acclimation temperature as the between-subject variable. Clearance rates for the warmest test temperature in winter $\left(20.6^{\circ} \mathrm{C}\right)$, 
which were beyond the linear relationship of clearance rates and temperature, were excluded for the analysis. Comparison of the clearance rates in the 4 experiments at the base temperature was tested using 1-factorial ANOVA. In the case of non-homogeneous variances, log-transformation was applied to achieve homogeneity of variances. Multiple pairwise comparisons were performed using REGW post-hoc tests. To test the similarity of the grazer community structures in the different seasons for both the flow cell experiments and the natural biofilms, Bray-Curtis similarity was calculated using the software Primer 6.1.5. Each replicate was considered as a separate unit. All data were $\log (x+1)$ transformed to reduce the impact of dominant groups. Significantly ( $\alpha=0.05$ ) separated clusters were determined using the SIMPROF-test. For the calibration of the method, a linear regression analysis of the dependence of community clearance rates at $19.7^{\circ} \mathrm{C}$ on the abundances of the grazers was performed and the $95 \%$ CI was calculated. For the second calibration experiment (potential losses of planktonic bacteria over bacterial biofilms), we compared the abundances of suspended bacteria in the in- and outflow of the flow cells using Student's $t$-test. Unless otherwise stated data presented are means $\pm \mathrm{SD}$.

\section{RESULTS}

\section{Experimental conditions}

The conditions during the experiments are summarized in Table 1. The base temperature conditions (i.e. the long-term mean temperatures in the Rhine for the particular time of the year) were close to the mean field temperatures during the acclimation period for all experiments. The abundances of suspended bacteria ranged between $0.89 \times 10^{6}$ cells $\mathrm{ml}^{-1}$ in autumn 05 and $3.07 \times$ $10^{6}$ cells $\mathrm{ml}^{-1}$ in summer 05 (Table 1). Bacteria in the River Rhine are generally small; $>80 \%$ of the bacteria found at any given time had a biovolume of $<0.1 \mu^{3}$.

\section{Calibration}

Because the performed measurement of community grazing rates of biofilm-dwelling protists and rotifers is novel, we tested whether or not losses of the planktonic bacteria were solely due to the activity of these grazers. The treatment of the biofilms from the autumn experiment with eukaryotic inhibitors resulted in a strong reduction of total ciliate and rotifer abundances, with the mean abundance of ciliates and rotifers being reduced from 43 to 11 ind. $\mathrm{cm}^{-2}$. The dependence of bacterial loss rate on grazer abundance (before and after inhibitor treatment) measured at $19.7^{\circ} \mathrm{C}$ revealed a linear relationship $(\mathrm{r}=0.85 ; \mathrm{p}<0.001)$. The intersection of the regression line and the $y$-axis was not different from $y=0$, as indicated by the 95\% CI (Fig. 1), showing that no other significant losses besides those to the eukaryotic grazers occurred. In the second calibration experiment, no significant differences in the abundances of suspended bacteria between the inand outflow were found ( $t$-test: $p=0.415)$ when the experiments were run with pure bacterial biofilms.

\section{Composition of the biofilm-dwelling grazer communities}

Groups of potential biofilm-associated grazers of suspended bacteria were primarily ciliates and rotifers. Ciliates were generally dominant in the flow cell experiments; the proportion of rotifers to the total

Table 1. Experimental conditions. The lowest acclimation temperature (equal to the first test-temperature step in the grazing experiments) corresponds to the annual average temperature in the Rhine calculated from the half-monthly averages since 1989

\begin{tabular}{|c|c|c|c|c|}
\hline Experiment conditions & Summer 05 & Autumn 05 & Winter 06 & Spring 06 \\
\hline Starting date & 08.06 .2005 & 20.10 .2005 & 04.01 .2006 & 08.05 .2006 \\
\hline $\begin{array}{l}\text { Mean temperature of the River Rhine } \\
\text { during exposure }\left({ }^{\circ} \mathrm{C}\right)\end{array}$ & 19.7 & 15.5 & 5.0 & 10.6 \\
\hline \multirow[t]{2}{*}{ Acclimation temperature $\left({ }^{\circ} \mathrm{C}\right)$} & 19.0 & & 6.6 & \\
\hline & 25.0 & 16.7 & 12.6 & 13.7 \\
\hline Test temperatures $\left({ }^{\circ} \mathrm{C}\right)$ & $\begin{array}{l}19.0 ; 23.0 \\
27.0 ; 31.0\end{array}$ & $16.7 ; 19.7 ; 22.7$ & $\begin{array}{l}6.6 ; 9.6 ; 12.6 ; \\
16.6 ; 20.6\end{array}$ & $\begin{array}{c}13.7 ; 16.7 \\
19.7 ; 22.7 ; 25.7\end{array}$ \\
\hline $\begin{array}{l}\text { Start abundance of planktonic bacteria } \\
\left(10^{6} \text { cells } \mathrm{ml}^{-1} \pm \mathrm{SD}\right)\end{array}$ & $3.07 \pm 0.22$ & $0.89 \pm 0.09$ & $1.68 \pm 0.11$ & $1.09 \pm 0.21$ \\
\hline $\begin{array}{l}\text { Size of bacteria }(\mu \mathrm{m}): 1 \text { st quartile, } \\
\text { median and 3rd quartile }\end{array}$ & $0.4 ; 0.7 ; 1.4$ & $0.4 ; 0,7 ; 1.0$ & $0.5 ; 0.7 ; 1.4$ & $0.4 ; 0.7 ; 1.1$ \\
\hline
\end{tabular}




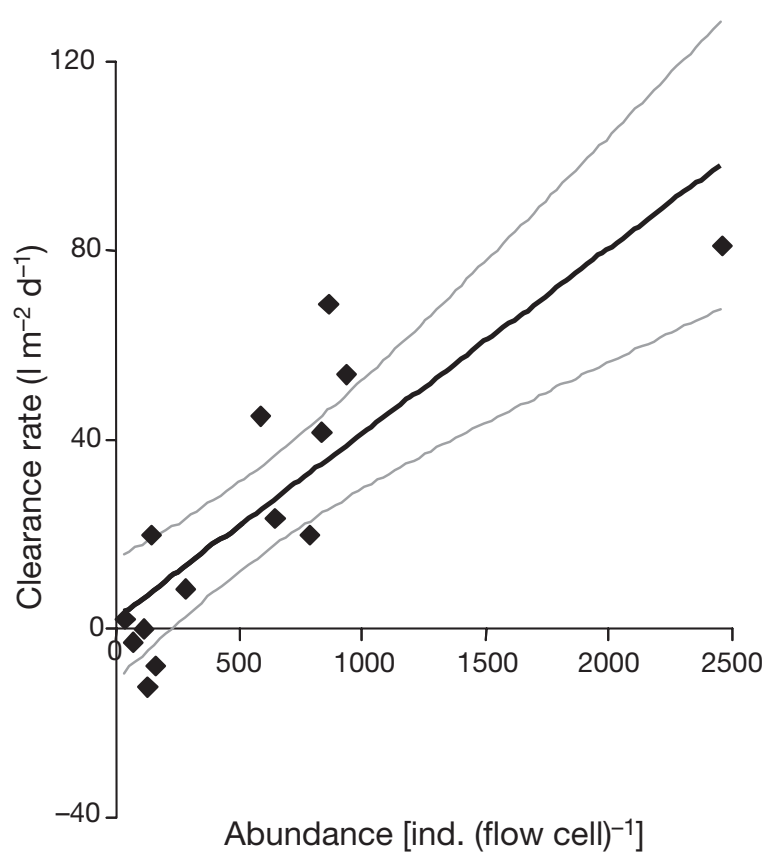

Fig. 1. Calibration of the flow cell experiments over the course of the autumn 05 experiment: dependence of community clearance rates on the abundance of grazers (ciliates and rotifers) at $19.7^{\circ} \mathrm{C}$. Grazing rates were measured with the regular pre-grown biofilms plus 4 additional pre-grown biofilms [data points above $x=500$ ind. (flow cell) ${ }^{-1}$ ] and after treatment with eukaryote inhibitors, which strongly (but not totally) reduced grazer abundance [data points below $x=500$ ind. (flow cell) ${ }^{-1}$ ]. The lines represent the linear regression line and the $95 \%$ CI. Note that the intersection of the regression line and the $y$-axis does not significantly differ from $y=0$

grazer biovolume was $<10 \%$ at the base acclimation temperatures on all 4 dates (Fig. 2D). The role of heterotrophic flagellates in this context is negligible due to their extremely low biomasses $(<1 \%$ of the total biomass of suspension feeders in the biofilm, see also Weitere et al. 2003). Total grazer (ciliates and rotifers) abundance at base temperature was highest in spring $06\left(386 \pm 103\right.$ ind $\left.\mathrm{cm}^{-2}\right)$ and lowest in autumn 05 (67 \pm 43 ind. $\mathrm{cm}^{-2}$, Fig. 2A), whereas grazer biovolume was greater in the summer experiment $\left(0.069 \pm 0.033 \mathrm{~mm}^{3}\right.$ $\left.\mathrm{cm}^{-2}\right)$ than in autumn $05\left(0.0015 \pm 0.0007 \mathrm{~mm}^{3} \mathrm{~cm}^{-2}\right)$, winter $06\left(0.0058 \pm 0.0016 \mathrm{~mm}^{3} \mathrm{~cm}^{-2}\right.$, and spring 06 $\left(0.013 \pm 0.0020 \mathrm{~mm}^{3} \mathrm{~cm}^{-2}\right.$; Fig. 2B). The large biovolume in summer 05 was due to the occurrence of large heterotrich ciliates (exclusively Stentor spp.) which made up $60 \%$ of the total grazer biovolume at this time but which were of minor importance in autumn 05, winter 06 and spring 06. Smaller choreotrichs and peritrichs dominated in autumn 05, whereas choreotrichs, peritrichs and cyrtophorids dominated in winter 06. In spring 06, the dominant groups in relation to total grazer biovolume were peritrichs, hypotrichs and haptorids. Groups of predominantly suspension-feeding organisms (i.e. rotifers as well as heterotrich, choreotrich and peritrich ciliates) contributed $\sim 80 \%$ to total grazer (ciliates and rotifers) biovolume in summer and autumn 05, but only 40 and $35 \%$ in winter and spring 06 (Fig. 2D).

Acclimation effects on the biofilm-associated grazer community in summer 05 and winter 06 (Fig. 2) were small in comparison to the large differences between the seasons as described above. In general, no significant differences (Student's $t$-test, $\mathrm{p}>0.05$ ) were found between the 2 acclimation treatments for both grazer abundance and biovolume, with the exception of a significant difference in grazer biovolume in winter 06 ( $p=0.032$; Fig. 2B). The larger biovolume for the warm acclimation $\left(12.6^{\circ} \mathrm{C}\right)$ coincided with a larger proportion of predominantly suspension-feeding groups (rotifers, peritrichs and choreotrichs) at this temperature (Fig. 2D). No obvious differences in the taxonomic composition between the 2 acclimation conditions were found for the summer 05 experiment.

The cluster analysis based on the Bray-Curtis similarity showed 2 significantly separated clusters (according to the SIMPROF test), one containing all replicates of the summer experiments and the other containing all replicates of the other experiments. These 2 clusters were separated by almost $80 \%$ dissimilarity. Within the large cluster, clear (although non-significant) separation of the different replicates for the winter, spring and autumn experiments were found, with the lowest dissimilarity ( 40\%) being between the winter and spring cluster. No significant separations were found between the replicates of the 2 acclimation conditions for either the summer or the winter experiments.

\section{Field communities on exposed substrates}

Ciliates were generally dominant within the natural biofilm-dwelling grazer communities from the River Rhine. The proportion of rotifers to the total grazer biovolume was $<20 \%$, except in spring 07 (>70\%; Fig. 3D). Total grazer abundance was highest in summer $07\left(2358 \pm 385\right.$ ind $\left.\mathrm{cm}^{-2}\right)$ and lowest in autumn 07 $\left(409 \pm 58\right.$ ind. $\mathrm{cm}^{-2}$; Fig. 3A), whereas grazer biovolume was larger in spring $07\left(0.360 \pm 0.184 \mathrm{~mm}^{3} \mathrm{~cm}^{-2}\right)$ than in summer $07\left(0.151 \pm 0.040 \mathrm{~mm}^{3} \mathrm{~cm}^{-2}\right)$, autumn $07\left(0.018 \pm 0.002 \mathrm{~mm}^{3} \mathrm{~cm}^{-2}\right.$, or winter 07 (0.055 \pm $0.010 \mathrm{~mm}^{3} \mathrm{~cm}^{-2}$; Fig. 3B). The large biovolume in spring 07 was due to the occurrence of large rotifers. Peritrichs and heterotrichs dominated in summer 07 , whereas the only dominant group in winter 07 was the peritrich ciliates ( $>80 \%$ of total grazer biovolume). In 

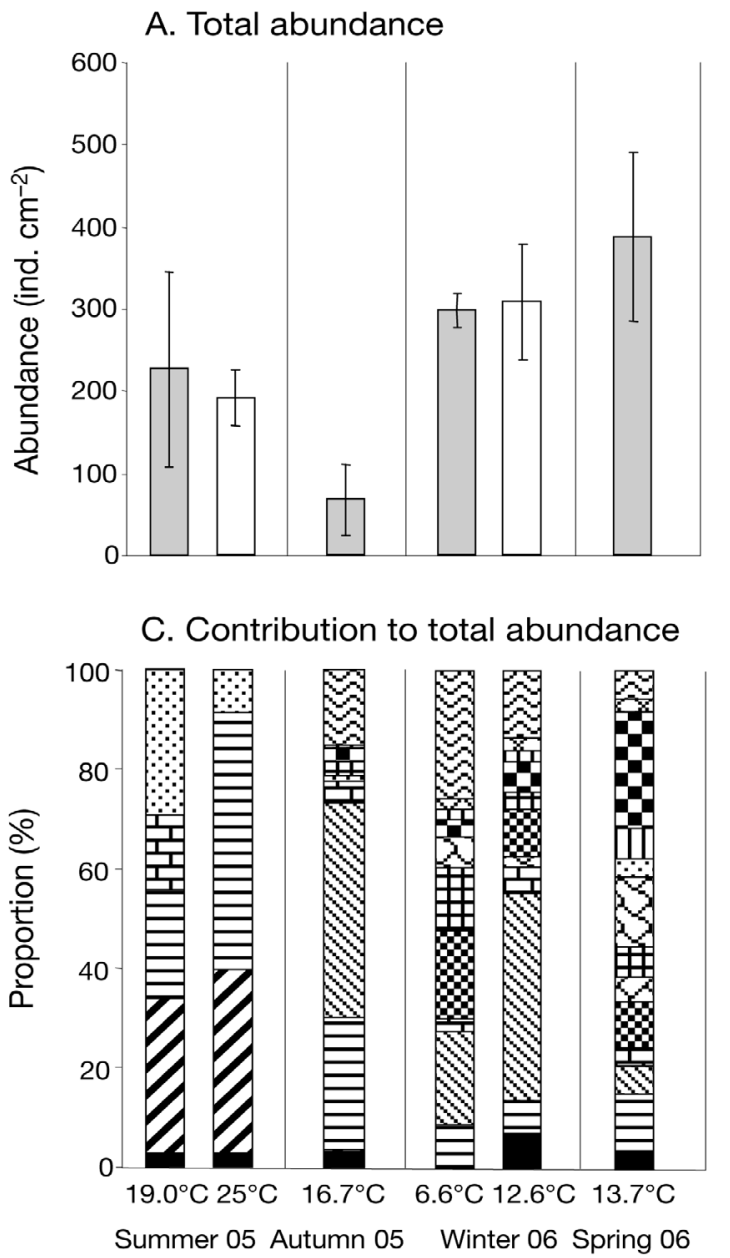
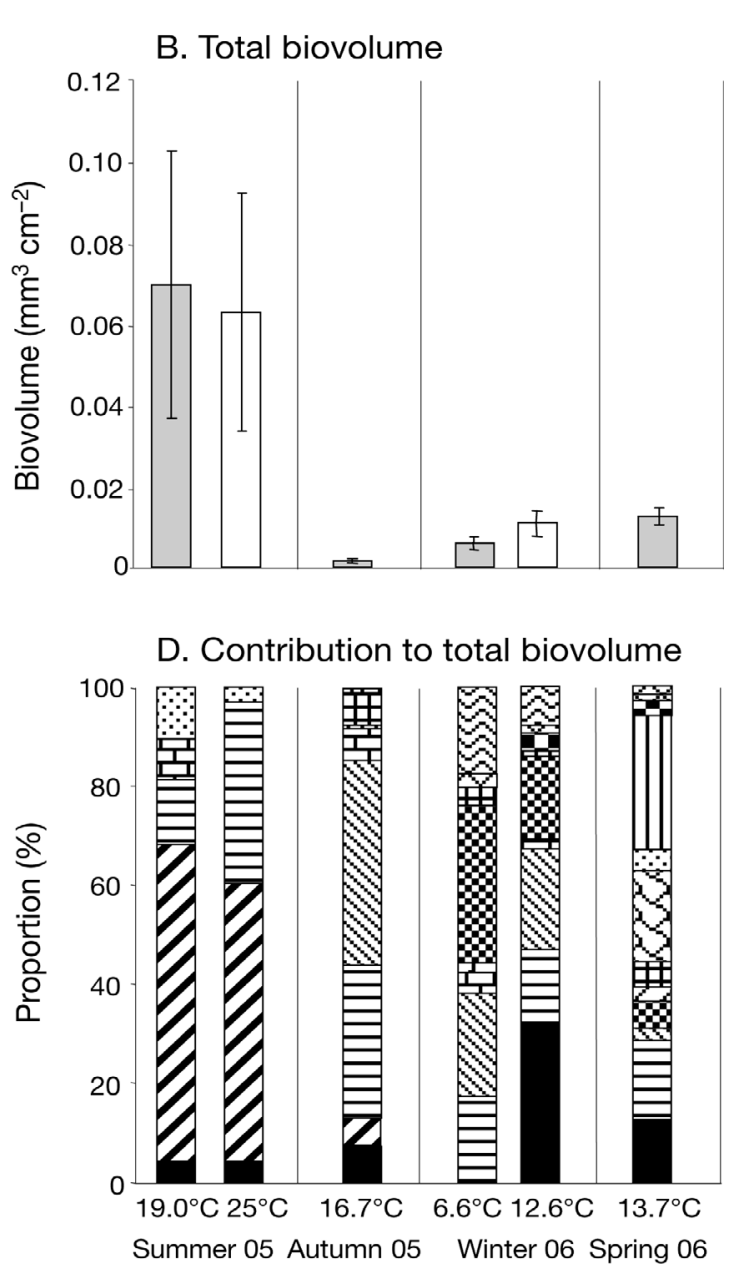

\begin{tabular}{|c|c|c|c|c|}
\hline$\triangle$ Undefined & \Nassophorea & Q Scuticociliatia & 1] Haptoria & $\because$ Hymenostomatia \\
\hline Q Prostomatea & BHypotrichia & 田 Litostomatea & $\triangle$ Suctoria & $\boldsymbol{B}$ Cyrtophoria \\
\hline 모 Stichotrichia & \Choreotrichia & $\boxminus$ Peritrichia & Z Heterotrichea & Rotifera \\
\hline
\end{tabular}

Fig. 2. Composition of the biofilm-dwelling grazer communities (ciliates and rotifers) which developed in the flow cell experiments at base temperatures in summer 05 , autumn 05 , winter 06 and spring 06 , and additionally at $6^{\circ} \mathrm{C}$ above base temperatures in summer 05 and winter 06. Mean $( \pm \mathrm{SD})(\mathrm{A})$ abundance and (B) biovolume. Contribution of taxa to (C) total abundance and

(D) total biovolume. Acclimation temperatures are given on the $X$-axes of panels $\mathrm{C}$ and $\mathrm{D}$

autumn 07, the biofilm communities were more heterogeneously structured and dominated by litostomatids, cyrtophorids and hymenostomatids. Groups of predominantly suspension-feeding organisms (i.e. rotifers as well as heterotrich, choreotrich and peritrich ciliates) contributed $\sim 90 \%$ to total grazer biovolume in spring, summer and winter 07 , but only $30 \%$ in autumn 07 (Fig. 3D). Cluster analysis based on the abundance data showed that the summer, winter and spring communities formed one cluster; the autumn community was significantly (SIMPROF-test: $\mathrm{p}<0.05$ ) dissimilar to the other biofilm communities.

\section{Grazing rates at base temperatures}

Comparison of the clearance rates on planktonic bacteria at base temperatures (acclimation to base temperature and clearance rate measurement at base temperature) for the different seasons revealed significant differences (see Table 2 for ANOVA results and Fig. 4 for post-hoc test results). The highest clearance rates per surface biofilm were measured in summer 05 $\left(99 \pm 11 \mathrm{l} \mathrm{m}^{-2} \mathrm{~d}^{-1}\right)$ and spring $06\left(69 \pm 32 \mathrm{l} \mathrm{m}^{-2} \mathrm{~d}^{-1}\right)$, followed by autumn $05\left(47 \pm 18 \mathrm{l} \mathrm{m}^{-2} \mathrm{~d}^{-1}\right)$ and winter 06 $\left(29 \pm 10 \mathrm{l} \mathrm{m}^{-2} \mathrm{~d}^{-1}\right.$; Fig. 4A). In contrast, per capita clear- 

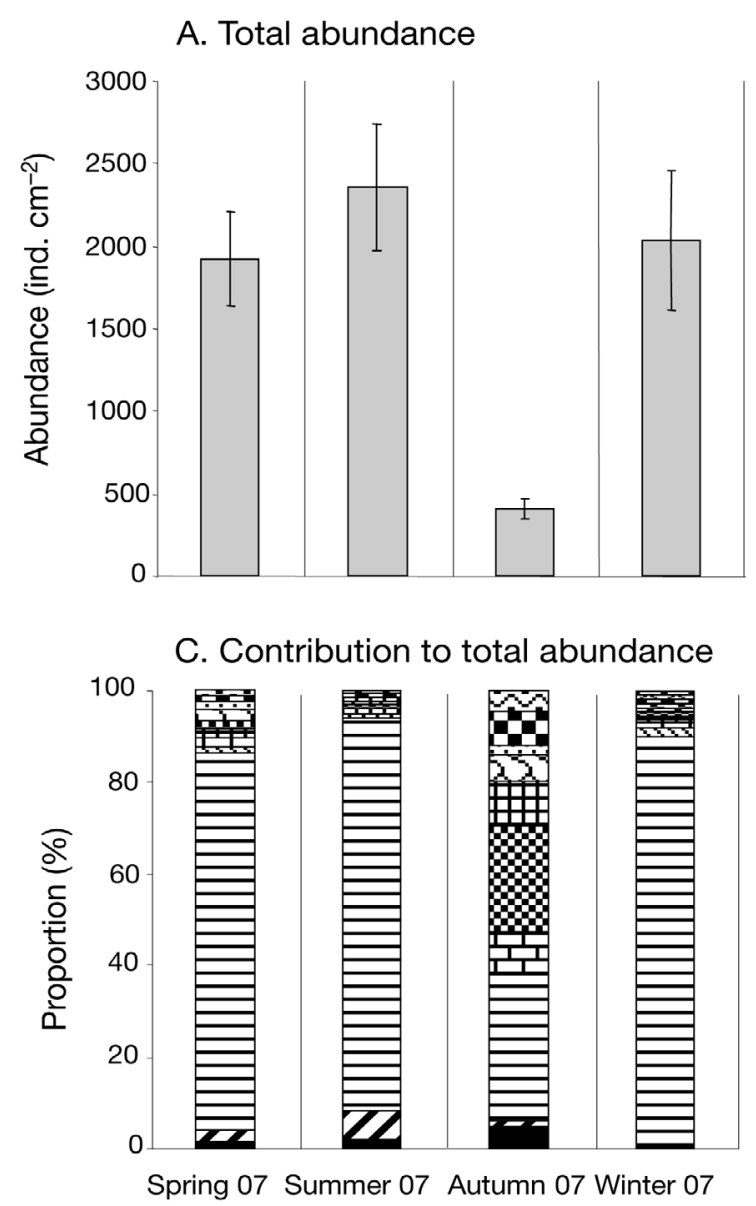

B. Total biovolume

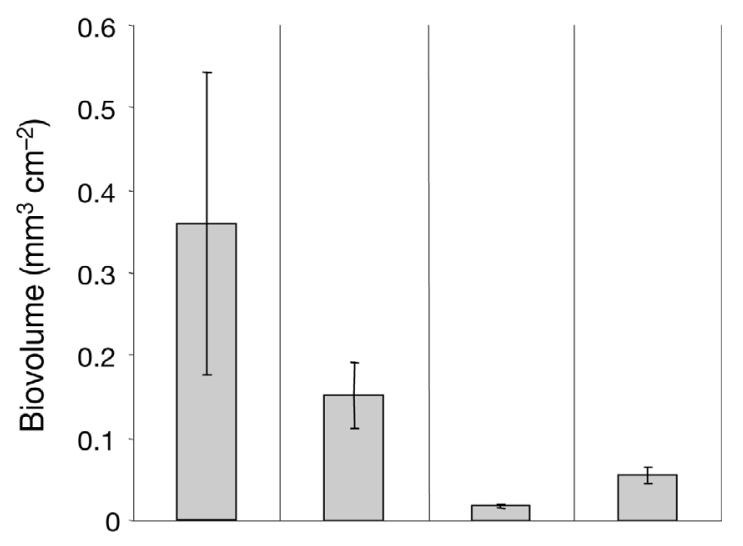

\section{Contribution to total biovolume}

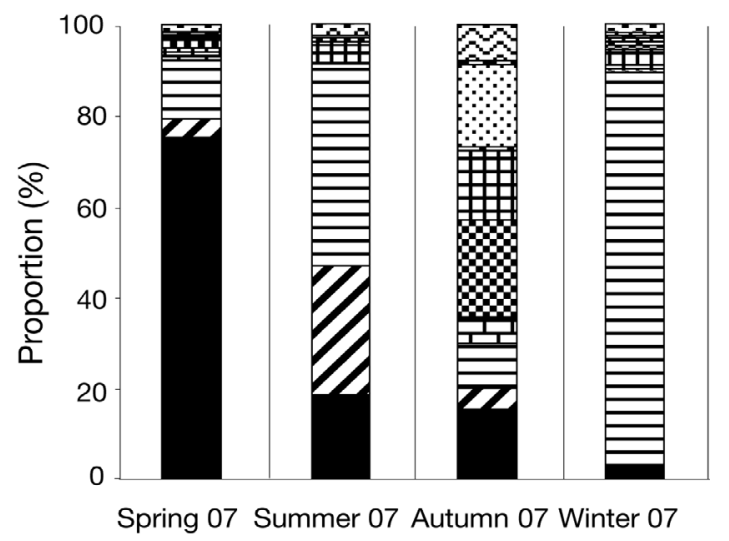

\begin{tabular}{|c|c|c|c|c|}
\hline QUndefined & QNassophorea & Ð Scuticociliatia & 四 Haptoria & $\because$ Hymenostomatia \\
\hline$\square$ Prostomatea & QHypotrichia & 田Litostomatea & Q Suctoria & $\otimes$ Cyrtophoria \\
\hline 回 Stichotrichia & S Choreotrichia & 日Peritrichia & $\square$ Heterotrichea & $\square$ Rotifera \\
\hline
\end{tabular}

Fig. 3. Composition of the natural (established on basalt tiles exposed to the main flow of the Rhine) biofilm-dwelling grazer communities (ciliates and rotifers) in the River Rhine in spring 07, summer 07, autumn 07 and winter 07. Mean ( \pm SD) (A) abundance and (B) biovolume. Contribution of taxa to (C) total abundance and (D) total biovolume

ance rates (Fig. 4B) were distinctly higher in autumn $05\left(4.7 \pm 0.9 \mu\right.$ ind. $\left.^{-1} \mathrm{~h}^{-1}\right)$ than in summer $05(2.3 \pm$ $1.3 \mu \mathrm{l}$ ind..$\left.^{-1} \mathrm{~h}^{-1}\right)$, winter $06\left(0.4 \pm 0.1 \mu \mathrm{lind} .^{-1} \mathrm{~h}^{-1}\right)$ and spring $06\left(0.7 \pm 0.2 \mu \mathrm{l}\right.$ ind. $\left.^{-1} \mathrm{~h}^{-1}\right)$. Significant differences in per capita clearance rates were found among all seasons, except between winter and spring 06 (Table 2, Fig. 4B). Clearance rates per grazer biovolume (Fig. 4C) were much higher in autumn 05 (3.0 \pm $\left.1.1 \mathrm{lmm}^{-3} \mathrm{~d}^{-1}\right)$ and in spring $06\left(1.8 \pm 0.71 \mathrm{~mm}^{-3} \mathrm{~d}^{-1}\right)$ than in summer $05\left(0.14 \pm 0.021 \mathrm{~mm}^{-3} \mathrm{~d}^{-1}\right)$ and winter $06\left(0.5 \pm 0.2 \mathrm{l} \mathrm{mm}^{-3} \mathrm{~d}^{-1}\right)$. Significant differences in clearance rates per biovolume were found among all seasons, except between autumn 05 and spring 06 (Table 2, Fig. 4C).

\section{Response of community grazing rates to temperature increases}

Temperature-dependent community grazing rates in different units (as ingestion and clearance rates, given per capita and per surface biofilm) are presented in Fig. 5. Grazing rates generally increased linearly with temperature, except for the experiment performed in spring 06 and for the warmest temperature in the winter 06 experiment. In spring 06, an increase in clearance rates was only observed between 13.7 (base temperature) and $16.7^{\circ} \mathrm{C}_{i}$ no increase was measured between 16.7 and $25.7^{\circ} \mathrm{C}$. Similar to the spring 06 experiment, clearance rates reached a plateau above 
A. Per surface biofilm
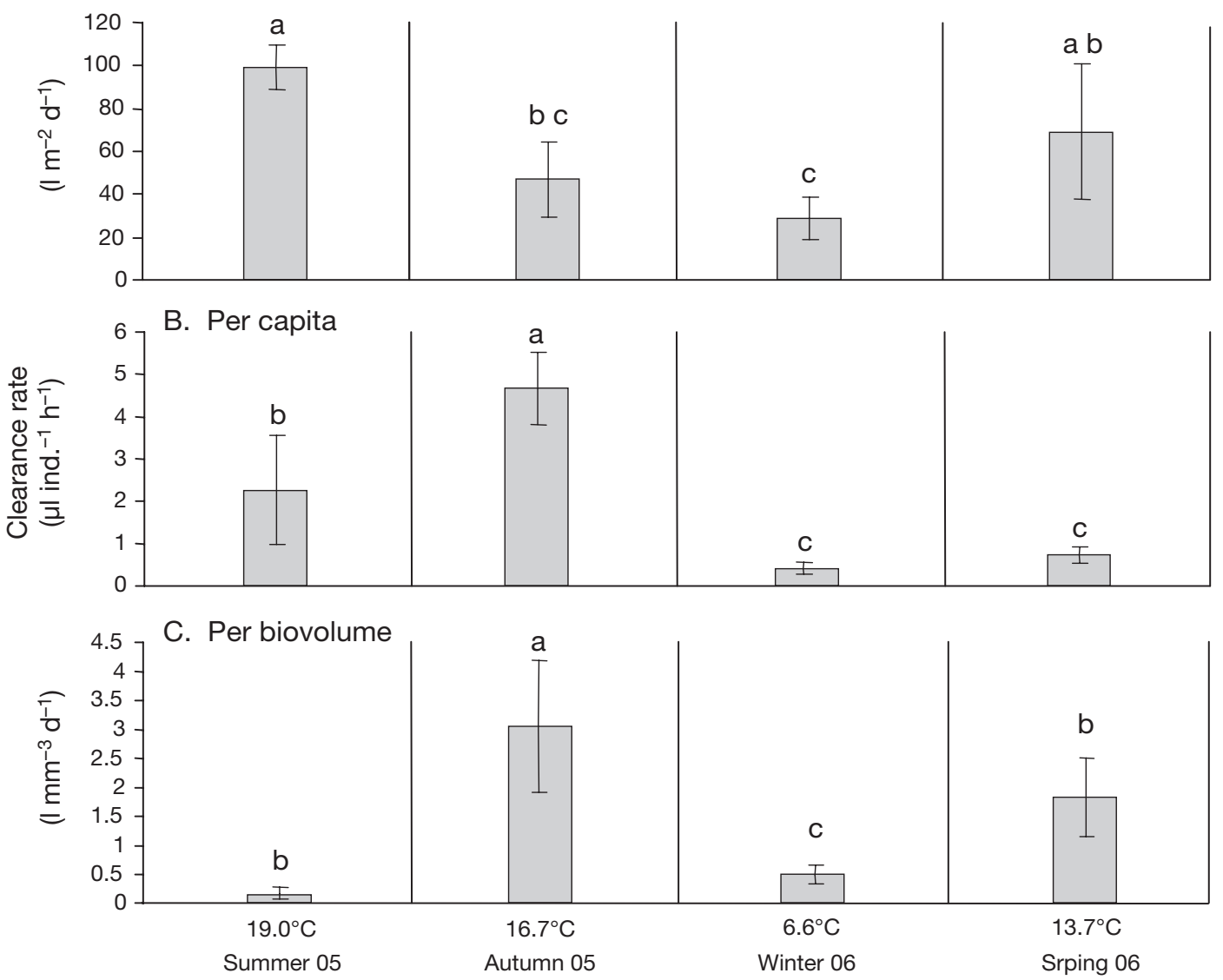

Fig. 4. Community clearance rates of the biofilms on suspended bacteria at base temperatures (acclimation and measurement at base temperatures). (A) Per surface biofilm clearance rates. (B) Per capita clearance rates. (C) Per grazer biovolume clearance rates. Clearance rates in each panel with different letters are significantly different (1-factorial ANOVA [Table 2] plus REGW post-hoc test)

$16.6^{\circ} \mathrm{C}$ in the winter 06 experiment after a linear increase at temperatures between 6.6 and $16.6^{\circ} \mathrm{C}$. In the other seasons, increases in clearance rates were observed over the total temperature range up to tem- peratures above the Rhine temperature at the particular season. In summer 05, linear increases in clearance rate with temperature were measured up to $31^{\circ} \mathrm{C}$, which was $12^{\circ} \mathrm{C}$ above the acclimation temperature.
Table 2. Results of 1-factorial ANOVAs testing the effect of season on clearance rates (separated per surface biofilm, per capita and per grazer biovolume) on suspended bacteria at base temperatures. Per capita and per biovolume clearance rates data were log-transformed. See Fig. 4 for results of REGW post-hoc test

\begin{tabular}{|c|c|c|c|c|c|}
\hline Clearance rate & & SS & $\mathrm{df}$ & $F$ & $\mathrm{p}$ \\
\hline \multirow{2}{*}{$\begin{array}{l}\text { Per surface biofilm } \\
\left(\mathrm{l} \mathrm{cm}^{-2} \mathrm{~d}^{-2}\right)\end{array}$} & Between seasons & 0.011 & 3 & \multirow[t]{2}{*}{9.36} & \multirow[t]{2}{*}{0.002} \\
\hline & Within seasons & 0.004 & 11 & & \\
\hline \multirow{2}{*}{$\begin{array}{l}\text { Per capita } \\
\left(\mu l \text { ind. }^{-1} \mathrm{~h}^{-1}\right)\end{array}$} & Between seasons & 0.759 & 3 & \multirow[t]{2}{*}{24.93} & \multirow[t]{2}{*}{$<0.001$} \\
\hline & Within seasons & 0.112 & 11 & & \\
\hline \multirow{2}{*}{$\begin{array}{l}\text { Per biovolume } \\
\left(\mathrm{l} \mathrm{mm}^{-3} \mathrm{~d}^{-1}\right)\end{array}$} & Between seasons & 3.838 & 3 & \multirow[t]{2}{*}{43.02} & \multirow[t]{2}{*}{$<0.001$} \\
\hline & Within seasons & 0.327 & 11 & & \\
\hline
\end{tabular}

\section{Acclimation effects on grazing rates}

The acclimation conditions (tested during the summer 05 and winter 06 experiments) had no significant impact on per capita clearance rates in summer (Fig. 5A; acclimation effect in ANOVA: $F_{1,6}=0.329 ; \mathrm{p}=0.587$ ) or on per surface biofilm clearance rate in summer (Fig. 5B; acclimation effect in ANOVA: $F_{1,6}=3.44 ; \mathrm{p}=0.113$ ). In winter 06, the warmer-acclimated biofilms (which harbored larger grazer biovolumes and larger proportions of 
Per capita
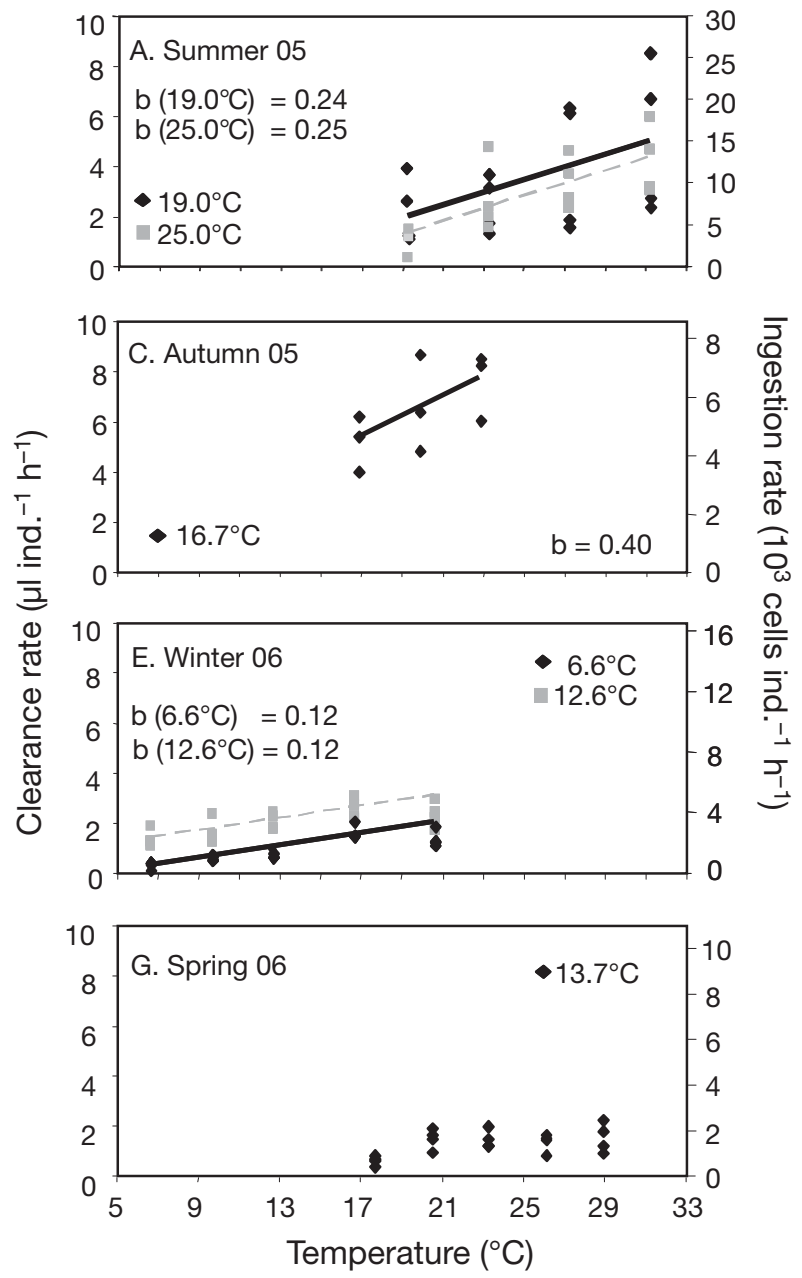
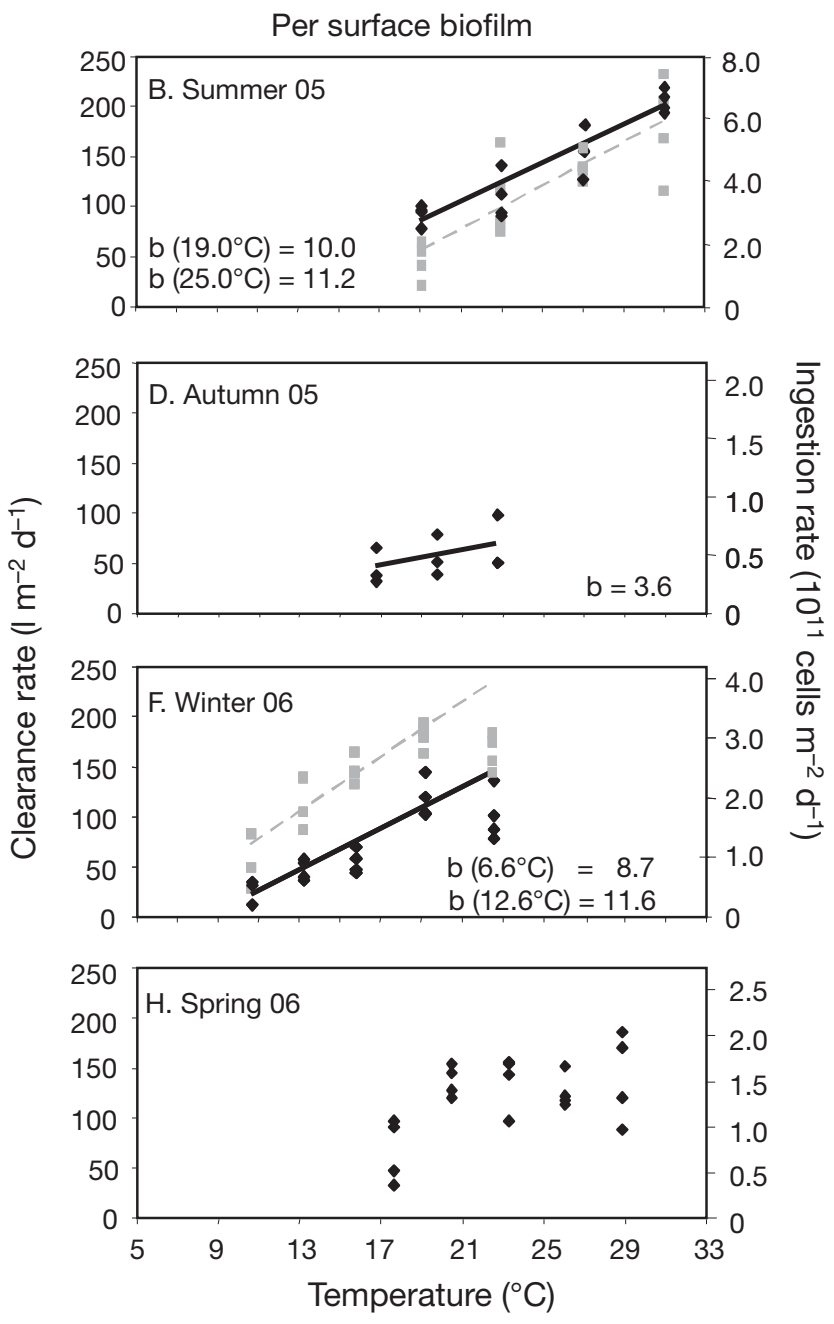

Fig. 5. Dependence of ingestion rates (right axes) and clearance rates (left axes) on test temperature ( $x$-axes) and acclimation temperature (different symbols). (A) Per capita and (B) per surface biofilm rates in summer 05 for acclimation to base temperature and to $6^{\circ} \mathrm{C}$ above base temperature. (C) Per capita and (D) per surface biofilm clearance rates in autumn 05 for acclimation to base temperature. (E) Per capita and (F) per surface biofilm clearance rates in winter 06 for acclimation to base temperature and to $6^{\circ} \mathrm{C}$ above base temperature. (G) Per capita and (H) per surface biofilm clearance rates in spring 06 for acclimation to base temperature. For the dependence of clearance rates on temperature, the slopes of the regression lines (b) are given in the panels when linear regressions were applied. Units of $b: \mu l$ ind. ${ }^{-1} \mathrm{~d}^{-1}{ }^{\circ} \mathrm{C}^{-1}$ for per capita clearance rates and $\mathrm{l} \mathrm{m}^{-2} \mathrm{~d}^{-1}{ }^{\circ} \mathrm{C}^{-1}$ for per surface biofilm clearance rates

predominantly suspension-feeding groups than the cold-acclimated biofilms; see section on 'Composition of the biofilm-dwelling grazer communities') showed a higher community clearance rate than the cold-acclimated biofilms (Fig. 5E,F). This difference was significant for both per capita and per surface biofilm clearance rates (acclimation effect in ANOVAs: $F_{1,6}=$ 309.01; $\mathrm{p}<0.001$ for per surface biofilm clearance rate and $F_{1,6}=63.854 ; \mathrm{p}<0.001$ for per capita clearance rate). Nevertheless, the optimal temperature for grazing did not differ between the acclimation temperatures in winter 06 in that the grazing rates decreased slightly between 16.6 and $20.6^{\circ} \mathrm{C}$ for both acclimation treatments.

\section{DISCUSSION}

\section{Applicability of grazing rate measurement in flow cells}

The measurement of community grazing rates of biofilm-dwelling protists and rotifers in a flow cell system is novel and thus needs critical evaluation as to whether or not losses of suspended bacteria were solely due to the feeding activity of benthic grazers. We were looking for a control method which selectively excludes grazers without influencing other possible causes of plankton losses (e.g. sedimentation or adherence of bacteria to the biofilm matrix). For this 
purpose, the biofilms in the autumn experiment were treated with the eukaryotic inhibitors cycloheximide and colchicine, which have been used for excluding eukaryotes but not prokaryotes (e.g. Newell et al. 1983, Sherr et al. 1986). Cycloheximide inhibits the 80S ribosomal function, which reduces lipid and protein syntheses, and colchicine inhibits microtubule polymerization, which finally inactivates cell division (see Taylor \& Pace 1987 and references therein). Studies have shown that these metabolic inhibitors affect the activity of eukaryotes, but have little, if any, influence on bacterial growth (e.g. Newell et al. 1983). However, some investigations with eukaryotic inhibitors have demonstrated that not all heterotrophic protists are similarly affected; a few protists remain in an active stage in the presence of the inhibitors (e.g. Taylor \& Pace 1987). Nevertheless, the goal of our manipulations was achieved because the treatment with cycloheximide and colchicine greatly reduced the abundances of ciliates and rotifers. The linear relationship between community grazing rates and grazer abundance, and the intersection of the regression line and $y$-axis being not significantly different from $y=0$ show that the losses of planktonic bacteria were predominantly due to the biofilm-dwelling grazers. In addition, we confirmed in the calibration experiment with grazer-free, untreated biofilm communities that the presence of bacterial biofilms alone did not lead to significant losses of planktonic bacteria. The consistent finding of no other significant losses of planktonic bacteria apart from those due to the eukaryotic grazers from the 2 calibration experiments supports the applicability of the flow cell method for the measurement of grazing on planktonic bacteria. However, we cannot fully exclude other residual losses that may have occurred below the detection level of the calibration experiments. Nevertheless, such losses, if present, were small in comparison to grazer-induced losses. Whether or not these results also apply to larger and heavier planktonic cells such as diatoms (which are more likely to be subject to sedimentation within the flow cells) needs to be tested in further experiments.

\section{Composition of the grazer community}

Before the start of all grazing experiments, the biofilm-associated grazer communities were quantified in the flow cells based on major taxonomic groups in consideration of ciliates and rotifers. The taxonomic composition of the biofilm-associated grazer communities were highly variable with respect to season. In summer 05, the analysed grazer communities consisted mainly of peritrich (e.g. Vorticella spp.) and heterotrich (exclusively Stentor spp.) ciliates that predom- inantly feed on suspended prey within the size spectrum of pico- to microplankton (e.g. Fenchel 1980, Kim et al. 2007). In terms of abundance, the third strongest major group of ciliates in this season were hymenostomes (e.g. Glaucoma scintillans). However, being relatively small-sized, this group of ciliates only contributed a small proportion to the total biofilmassociated grazer biovolume and was thus not expected to significantly reduce plankton from the water column. The large proportion of biofilm-dwelling planktivorous ciliates probably reflects the high availability of suspended prey (bacteria and microalgae) during early summer (Weitere et al. 2005b).

In autumn 05, the abundances and biovolumes of all biofilm-associated grazers were rather small compared to those in the other seasons. However, the grazer community was again dominated by filter-feeding species of the major groups Peritrichia and Choreotrichia ( $~ 80 \%$ contribution to both total abundance and total biovolume). Like peritrichs, choreotrichs are also predominantly filter-feeding ciliates which can efficiently graze on suspended particles (Heinbokel 1978, Fenchel 1980). Thus, both the summer and autumn communities were mainly dominated by suspension-feeding groups, which is in accordance with the composition of other periphytic ciliate communities (e.g. Gong et al. 2005, Primc-Habdija et al. 2005). Choreotrichs predominantly occur in the plankton. However, we frequently found 2 species within the biofilm communities that show specific adaptations to surface-attached life: Tintinnidium semiciliatum, which inhabit an irreversibly surface-attached lorica (Foissner et al. 1991), and Strobilidium caudatum, which can attach and detach itself to the substrate using a stalk (see Grim \& Halcrow 1979 on Strobilidium gyrans; this species name is considered to be a synonym for Strobilidium caudatum by Foissner 1987, see also Foissner et al. 1991).

In the winter 06 experiment, no clear domination by any single major ciliate group was observed. However, the total biovolume of biofilm-associated grazers was significantly higher in the warmed flow cells than in those at the base temperature, due to a higher number of choreotrich ciliates and rotifers. In terms of function, a greater number of suspension-feeding taxa were present in the warmer-acclimated flow cells, which could potentially account for higher clearance rates in the grazing experiments. Nevertheless, no significant dissimilarities (Bray-Curtis) between the communities established under the 2 acclimation temperatures could be demonstrated in the cluster analyses.

In spring 06, the biofilm-dwelling grazer community was heterogeneous, with significant contributions from vagile taxa of the major groups Hypotrichia, Haptoria and Litostomatea (the latter 2 being predatory), which all predominantly feed on biofilm-associated prey 
(Franco et al. 1998); planktivorous ciliate species such as scuticociliates (e.g. Cyclidium glaucoma) and peritrichs accounted for only a small proportion of the biovolume. This community structure resembled a winter rather than a typical spring community, in which more planktivorous filter feeders utilize the seasonal bloom of microalgae (Esser 2006). This similarity of winter and spring communities was supported by the cluster analysis. The community structure indicates a low average per capita grazing rate on planktonic resources for the winter and spring experiments.

The communities established in the flow cells (Fig. 2) differed from those in the field (Fig. 3). Total grazer abundances were distinctly (almost an order of magnitude) higher in the field communities. Furthermore, the field communities were more strongly dominated by suspension-feeding groups, particularly by peritrichs and (in spring) by large-sized rotifers, which contributed strongly to grazer biovolume. Similar to the flow cell communities, plankton-consuming heterotrichs (the genus Stentor) were particularly common in summer. Overall, the differences thus suggest a distinctly higher per surface biofilm grazing rate in the field communities than in the communities established in flow cells. Quantitative comparisons with field situations thus need to be treated with caution, although the focus of this study was on the patterns of grazing rates in response to temperature in these complex communities.

\section{Seasonal comparison of grazing rates at base tem- peratures}

Both the average per capita clearance rate and the average per capita ingestion rate measured here are functions of several factors including the energetic demand of the grazers, their feeding preferences, temperature, and prey concentrations (e.g. Rothhaupt 1990, Weisse et al. 2002). The low per capita clearance rates in winter and spring (Fig. 4B) correlate with low temperatures and low contributions of planktivorous ciliates to the total grazer community (Fig. 2C,D). The lower per capita clearance rate found in summer compared to autumn is probably due to the higher abundances of heterotrichs (Stentor spp.), which feed on plankton but prefer particles larger than bacteria (Kim et al. 2007). The large biovolume of Stentor spp., a genus which probably exerts only a relatively small grazing pressure on bacteria, also explains the very low per biovolume clearance rate in summer (Fig. 4C). In addition, the large-bodied ciliates have a lower per body mass metabolic rate and food demand (e.g. Müller \& Geller 1993, Gillooly et al. 2001). The clearance rates per surface biofilm are a function of the average per capita clearance rates and ciliate abun- dance. Due to the high abundances of ciliates in spring, the clearance rates per surface biofilm were similarly high as in summer (Fig. 4A).

The absolute clearance and ingestion rates measured here were high compared to rates given in the literature, even though we calculated the rates as the average over all grazers including predominantly benthivorous grazers. While Simek et al. $(1995,2000)$ measured rates of a similar range as that found in our study for both planktonic ciliate communities and single species at temperatures between 14 and $23^{\circ} \mathrm{C}$, other rates measured for planktonic ciliate communities and single species at comparable temperature ranges were distinctly lower (e.g. Sherr et al. 1988, Hadas et al. 1998). That rotifers also moderately contribute to grazer abundance cannot explain why the grazing rates measured here were higher than those in the literature. Rotifer biovolumes were not distinctly larger than ciliate biovolumes (compare Fig. 2C \& D). The maximum average ingestion rate of 3200 bacteria rotifer $^{-1} \mathrm{~h}^{-1}$ for planktonic rotifer communities recorded by Sanders et al. (1989) at temperatures between 7.8 and $30.2^{\circ} \mathrm{C}$ was not higher than the average per capita rates measured here at high temperatures. The high grazing rates measured here could therefore be seen as typical for biofilm-associated micrograzer communities. On average, biofilms harbor distinctly larger ciliate species than the plankton. Therefore, one must be cautious when using clearance rates measured for planktonic ciliates to calculate grazing rates of biofilm communities.

In addition to temperature (see next section), flow conditions can also influence clearance rates of biofilm-dwelling consumer communities. Flow conditions can either directly alter ingestion rates (e.g. Shimeta et al. 2001, Peters et al. 2002) or indirectly do so by influencing the local abundance and composition of the grazer community (e.g. Shimeta et al. 2007, Willkomm et al. 2007). Such effects need to be considered when extrapolating clearance rates obtained in the laboratory to the field. However, because the focus of the present study was on the temperature response, we kept the flow conditions constant during the experiments.

\section{Grazing response to increasing temperature}

For ectotherms, temperature is one of the strongest factors that influence biological rates such as respiration rate (e.g. Gillooly et al. 2001, Savage et al. 2004), growth rate (e.g. Müller \& Geller 1993, Weisse et al. 2002) and feeding rate (Montagnes et al. 2001, Viergutz et al. 2007). An increase in temperature generally has a stimulating effect on biological rates within a species-specific optimal temperature range. Feeding 
rate in particular usually shows exponential or rectilinear dependencies on temperature in metazoans (e.g. Viergutz et al. 2007). In this study, we recorded linear relationships between temperature and community grazing rates. This average response is the result of the individual responses of several species within the grazer community. It is remarkable that the increases were observed even up to a high summer temperature of $31^{\circ} \mathrm{C}$. The feeding rates of most ectothermic animals (including macrobenthic filter feeders) of moderate climates were found to decrease strongly with warming at such high temperatures (e.g. Viergutz et al. 2007, Weitere et al. 2008). Biofilm-associated consumer communities can therefore still efficiently graze on their prey at temperatures that render filter feeding by benthic macrofauna inefficient. This could be relevant in the context of global warming since it is likely that the frequency of summer heat waves will increase in the near future (Schär et al. 2004).

The response of grazing rates to increased temperature also depends on the specific grazer community established during particular seasons. While linear relationships were recorded over the total temperature range in summer and autumn 05, no further increases of the grazing rates were recorded beyond $17^{\circ} \mathrm{C}$ in either the winter 06 or spring 06 communities. While this upper limit of the linear relationship is far above the field temperature in winter 06, it is much closer to the field temperature in spring 06. The composition of the spring community (Fig. 2) resembles that of a winter community, as discussed above (see section on 'Composition of the grazer community'). Particularly the large-bodied heterotrichs, which are typical components of spring and summer communities, were absent in spring 06. It seems that the spring community still harbors a more typical winter community, with colder-adapted species having lower temperature optima. Thus, communities in the transition from cold to warm periods might be more susceptible to warming in that their grazing rates do not increase within the same wide temperature range as communities established under other seasonal settings. However, the temperature optima of protists can differ between species and even between clones within a species (e.g. Weisse \& Montagnes 1998, Weisse 2002, Gachter \& Weisse 2006). Cryptic variations in the community structure beyond the detection level of our taxonomic analyses could also account for the different temperature responses of community grazing rates.

\section{Acclimation effects}

Aside from test temperature effects, both metabolic and feeding rates may also be influenced by acclima- tion conditions. Generally, individual organisms reduce their metabolic activity and thus their food demand when exposed to high temperatures for longer durations (Randall et al. 2004). In the case of the community grazing rates of fast-growing ciliate communities, however, 2 processes of acclimation need to be considered: the acclimation of the individual, and the response of the community to the temperature changes in terms of structure and density. The abundance of a community can be positively influenced by a temperature increase in early succession stages due to the stimulation of growth rates (e.g. Müller \& Geller 1993, Weisse et al. 2002). In late succession stages, however, temperature increases could have a negative effect on the carrying capacity, balancing the effect of increasing metabolic costs (Savage et al. 2004). These contrasting effects of temperature on the abundance of early- and late-stage communities were demonstrated recently in biofilm-associated ciliate communities (Norf et al. 2007). In the present study, a non-significant trend of a smaller ciliate biovolume with high acclimation temperature in summer 05 and a significantly higher ciliate biovolume with high temperature in winter 05 was demonstrated (Fig. 2B). These findings coincided with theoretical considerations of the effect of temperature on community abundance in that a plateau in the abundance was reached in the summer community after $\sim 7 \mathrm{~d}$ and in the winter community after $\sim 21 \mathrm{~d}$ (Norf et al. 2007). The $2 \mathrm{wk}$ exposure here therefore reflects a more early stage in winter 06 and more mature stage in summer 05 , with positive and negative effects of warming on the abundance, respectively. These effects of acclimation temperature on abundance probably provide an important explanation for the trend of reduced per surface clearance rates in the warm-acclimated community in summer 05 and the significantly enhanced per surface clearance rates in the warm-acclimated community in winter 05 (Fig. 5). Nevertheless, the per capita clearance rates were also significantly higher for the warm-acclimated community in winter 06 . One important reason for this finding is that not only the total abundance but also the ciliate community structure is influenced by the acclimation temperature. The biovolume of suspension feeders in the biofilm-associated consumer community, particularly the biovolume of rotifers in winter 06, increased with an increase in acclimation temperature (Fig. 2D). Furthermore, it is known that the temperature reaction norm can show interspecific differences (e.g. Gachter \& Weisse 2006), leading to the possibility that different acclimation temperatures also select for clones within morpho-species which perform differently under changing temperatures.

In summary, the results of the acclimation experiments show that community grazing rates are not only 
affected by the actual temperature, but also by the acclimation conditions. In contrast to the acclimation of individual grazing rates, community grazing rates of fast-growing biofilm communities may also depend on the effect of temperature on the community structure.

\section{CONCLUSIONS}

The results demonstrate pronounced differences in the temperature response of community feeding rates of biofilm-dwelling consumers compared to responses known for filter-feeding macrofauna. Such differences need to be considered when predicting the impact of temperature changes on plankton communities controlled by benthos. Furthermore, we demonstrate that suspension-feeding groups dominate the natural biofilm consumer communities in the lower Rhine River. Their average per capita feeding rates on suspended bacteria are similar to the highest rates demonstrated for planktonic ciliate communities (see section on 'Seasonal comparison of the grazing rates at base temperatures' for detailed discussion). The introduced flow cell method also provides initial quantitative data on community grazing rates of such complex, naturally growing biofilms. First rough estimates suggest that per surface clearance rates could be in the order of $1000 \mathrm{l} \mathrm{m}^{-2} \mathrm{~d}^{-1}$ in the field in summer (when considering a rate of $100 \mathrm{l} \mathrm{m}^{-2} \mathrm{~d}^{-1}$ as measured in the flow cell (Fig. 4A) and the 10-fold higher abundance in the field communities (Fig. 3A) compared to the flow cell communities (Fig. 2A), which would be in a similar range as calculated for bivalves (compare Schöl et al. 2002). Nevertheless, such quantitative estimates were not the main goal of the present study, and caution is advised when extrapolating the per surface clearance rates as measured here to that in the field. Further research, e.g. on the impact of the flow conditions at the river bottom, are needed in order to more accurately estimate the systemwide impact of biofilmdwelling grazer communities.

Acknowledgements. This study is part of the priority program 'Impact of climate variability on aquatic ecosystems (AQUASHIFT)' funded by the German Research Foundation (DFG). We thank M. Gies for the analysis of the biofilm data in the spring experiment, R. Bieg for gathering the temperature and water level data for the River Rhine, and F. Bartlett for critical comments and for improving the language of the manuscript.

\section{LITERATURE CITED}

Adl SM, Simpson AGB, Farmer MA, Andersen RA and others (2005) The new higher level classification of eukaryotes with emphasis on the taxonomy of protists. J Eukaryot Microbiol 52:399-451
Arndt H, Schmidt-Denter K, Auer B, Weitere M (2003) Protozoans and biofilms. In: Krumbein WE, Paterson DM, Zavarzin GA (eds) Fossil and recent biofilms, mats and networks. Kluwer Academic Publishers, Dordrecht, p 173-189

Caraco NF, Cole JJ, Strayer DL (2006) Top-down control from the bottom: regulation of eutrophication in a large river by benthic grazing. Limnol Oceanogr 51:664-670

Esser M (2006) Long-term dynamics of microbial biofilm communities in the River Rhine. PhD thesis, University of Cologne

Fenchel T (1980) Suspension feeding in ciliated protozoa: feeding rates and their ecological significance. Microb Ecol 6:13-25

Fischer H, Pusch M (2001) Comparison of bacterial production in sediments, epiphyton and the pelagic zone of a lowland river. Freshw Biol 46:1335-1348

Foissner W (1987) Miscellanea nomenclatorica ciliatea (Protozoa: Ciliophora). Arch Protistenkd 133:219-235

Foissner W, Berger H (1996) A user-friendly guide to the ciliates (Protozoa, Ciliophora) commonly used by hydrobiologists as bioindicators in rivers, lakes and waste waters, with notes on their ecology. Freshw Biol 35:375-482

Foissner W, Blatterer H, Berger H, Kohmann F (1991) Taxonomische und ökologische Revision der Ciliaten der Saprobiensystems, Band I. Cyrtophorida, Oligotrichida, Hypotrichia, Colpodea. Informationsberichte des Bayer. Landesamtes für Wasserwirtschaft, Heft 1/91, Munich, p 478

Franco C, Esteban GF, Tellez C (1998) Colonisation and succession of ciliated Protozoa associated with submerged leaves in a river. Limnologica 28:275-283

Gachter E, Weisse T (2006) Local adaptation among geographically distant clones of the cosmopolitan freshwater ciliate Meseres corlissi. I. Temperature response. Aquat Microb Ecol 45:291-300

Gillooly JF, Brown JH, West GB, Savage Van M, Charnov EL (2001) Effects of size and temperature on metabolic rate. Science 293:2248-2251

Gong J, Song WB, Warren A (2005) Periphytic ciliate colonization: annual cycle and responses to environmental conditions. Aquat Microb Ecol 39:159-170

Grim JN, Halcrow KR (1979) The oligotrich ciliate Strobilidium gyrans: its freshwater environment, laboratory culture conditions, and stalking behaviour. Trans Am Microsc Soc 98:529-536

- Hadas O, Malinsky-Rushansky N, Pinkas R, Cappenberg TE (1998) Grazing on autotrophic and heterotrophic picoplankton by ciliates isolated from Lake Kinneret, Israel. J Plankton Res 20:1435-1448

Hall-Stoodley L, Costerton JW, Stoodley P (2004) Bacterial biofilms: from the natural environments to infectious diseases. Nat Rev Microbiol 2:95-108

- Heinbokel JF (1978) Studies on functional role of tintinnids in southern California Bight. 2. Grazing rates of field populations. Mar Biol 47:191-197

Hillebrand $\mathrm{H}$, Durselen CD, Kirschtel D, Pollingher U, Zohary $\mathrm{T}$ (1999) Biovolume calculation for pelagic and benthic microalgae. J Phycol 35:403-424

Hillebrand $H$, Kahlert $M$, Haglund AL, Berninger UG, Nagel S, Wickham S (2002) Control of microbenthic communities by grazing and nutrient supply. Ecology 83: 2205-2219

- Huws SA, McBain AJ, Gilbert P (2005) Protozoan grazing and its impact upon population dynamics in biofilm communities. J Appl Microbiol 98:238-244

Kim YO, Chang M, Ka SK, Han MS (2007) Grazing on algae 
and growth of the freshwater heterotrich ciliate Stentor roeseli. J Freshw Ecol 22:361-363

Montagnes DJS, Kimmance SA, Tsounis G, Gumbs JC (2001) Combined effect of temperature and food concentration on the grazing rate of the rotifer Brachionus plicatilis. Mar Biol 139:975-979

> Mulholland PJ, Steinmann AD, Marzhof ER, Hart DR, DeAngelis DL (1994) Effect of periphyton biomass on hydraulic characteristics and nutrient cycling in streams. Oecologia 98:40-47

Müller H, Geller W (1993) Maximum growth rates of aquatic ciliated protozoa: the dependence on body size and temperature reconsidered. Arch Hydrobiol 126:315-327

> Newell SY, Sherr BF, Sherr EB, Fallon RD (1983) Bacterial response to presence of eukaryote inhibitors in water from a coastal marine environment. Mar Environ Res 10: $147-157$

Norf H, Arndt H, Weitere M (2007) Impact of local temperature increase on the early development of biofilm-associated ciliate communities. Oecologia 151:341-350

Parry JD (2004) Protozoan grazing of freshwater biofilms. Adv Appl Microbiol 54:167-196

> Peters F, Marrase C, Havskum H, Rassoulzadegan F, Dolan J, Alcaraz M, Gasol JM (2002) Turbulence and the microbial food web: effects on bacterial losses to predation and community structure. J Plankton Res 24:321-331

Porter K, Feig Y (1980) The use of DAPI for identifying and counting aquatic microflora. Limnol Oceanogr 25:943-948

Primc-Habdija B, Habdjia I, Matonickin R, Spoljar M (2005) Development of ciliate community on artificial substrates associated with vertical gradients of environmental conditions in a karstic lake. Arch Hydrobiol 164:513-527

Randall DJ, Burggren W, French K (2004) Eckert animal physiology, 5th edn. Palgrave Macmillan, Basingstoke

Rothhaupt KO (1990) Changes of the functional responses of the rotifers Brachionus rubens and Brachionus calyciflorus with particle sizes. Limnol Oceanogr 35:24-32

Sanders RW, Porter KG, Benett SJ, DeBiasw AE (1989) Seasonal patterns of bacterivory by flagellates, ciliates, rotifers, and cladocerans in a freshwater planktonic community. Limnol Oceanogr 34:673-687

Sanford E (1999) Regulation of keystone predation by small changes in ocean temperature. Science 283:2095-2097

Savage VM, Gillooly JF, Brown JH, West GB, Charnov EL (2004) Effects of body size and temperature on population growth. Am Nat 163:429-441

Schär C, Vidale PL, Lüthi D, Frei C, Häberli C, Liniger MA, Appenzeller C (2004) The role of increasing temperature variability in European summer heatwaves. Nature 427: 332-336

Schöl A, Kirchesch V, Bergfeld T, Schöll F, Borcherding J, Müller D (2002) Modelling the chlorophyll a content of the River Rhine: interrelation between riverine algal production and population biomass of grazers, rotifers and the zebra mussel Dreissena polymorpha. Int Rev Hydrobiol 87:295-317

> Sherr BF, Sherr EB, Andrew TL, Fallon RD, Newell SY (1986) Trophic interactions between heterotrophic Protozoa and bacterioplankton in estuarine water analyzed with selective metabolic inhibitors. Mar Ecol Prog Ser 32:169-179

Sherr BF, Sherr EB, Rassoulzadegan F (1988) Rates of digestion of bacteria by marine phagotrophic Protozoa: temperature dependence? Appl Environ Microbiol 54:1091-1095
Shimeta J, Starczak VR, Ashiru OM, Zimmer CA (2001) Influences of benthic boundary-layer on feeding rates of ciliates and flagellates at the sediment-water interface. Limnol Oceanogr 46:1709-1719

Shimeta J, Gast RJ, Rose JM (2007) Community structure of marine sedimentary protists in relation to flow and grain size. Aquat Microb Ecol 48:91-104

Simek K, Bobkova J, Macek M, Nedoma J (1995) Ciliate grazing on picoplankton in a eutrophic reservoir during the summer phytoplankton maximum: a study at the species and community level. Limnol Oceanogr 40:1077-1090

- Simek K, Jürgens K, Nedoma J, Comerma M, Armengol J (2000) Ecological role and bacterial grazing of Halteria spp.: small freshwater oligotrichs as dominant pelagic ciliate bacterivores. Aquat Microb Ecol 22:43-56

> Taylor GT, Pace ML (1987) Validity of eukaryote inhibitors for assessing production and grazing mortality of marine bacterioplankton. Appl Environ Microbiol 53:119-128

- Viergutz C, Kathol M, Norf H, Arndt H, Weitere M (2007) Control of microbial communities by the macrofauna: a sensitive interaction in the context of extreme summer temperatures? Oecologia 151:115-124

Weisse T (2002) The significance of inter- and intraspecific variation in bacterivorous and herbivorous protists. Antonie van Leeuwenhoek 81:327-341

Weisse T, Montagnes DJS (1998) Effect of temperature on inter- and intraspecific isolates of Urotricha (Prostomatida, Ciliophora). Aquat Microb Ecol 15:285-291

Weisse T, Stadler P, Lindström ES (2002) Interactive effect of temperature and food concentration on growth rate: a test case using the small freshwater ciliate Urotricha farcta. Limnol Oceanogr 47:1447-1455

Weitere M, Arndt H (2002) Water discharge-regulated bacteria/heterotrophic nanoflagellate (HNF) interactions in the water column of the River Rhine. Microb Ecol 44:19-29

Weitere M, Schmidt-Denter K, Arndt H (2003) Laboratory experiments on the impact of biofilms on the plankton of a large river. Freshw Biol 48:1983-1992

> Weitere M, Bergfeld T, Rice SA, Matz C, Kjelleberg S (2005a) Grazing resistance of Pseudomonas aeruginosa biofilms depends on type of protective mechanism, developmental stage and protozoan feeding mode. Environ Microbiol 7 : 1593-1601

Weitere M, Scherwass A, Sieben KT, Arndt H (2005b) Planktonic food web structure and potential carbon flow in the lower River Rhine with a focus on the role of protozoans. River Res Appl 21:535-549

Weitere M, Dahlmann J, Viergutz C, Arndt H (2008) Differential grazer-mediated effects of high summer temperatures on pico- and nanoplankton communities. Limnol Oceanogr 53:477-486

Welker M, Walz N (1998) Can mussels control the plankton in rivers? A planktological approach applying a Lagrangian sampling strategy. Limnol Oceanogr 43:753-762

Wetzel RG (2001) Limnology: lake and river ecosystems, 3rd edn. Academic Press, San Diego, CA

Willkomm M, Schlüssel A, Reiz E, Arndt H (2007) Effects of microcurrents in the boundary layer on the attachment of benthic heterotrophic nanoflagellates. Aquat Microb Ecol 48:169-174

> Winder M, Schindler DE (2004) Climate change uncouples trophic interactions in an aquatic ecosystem. Ecology 85: 2100-2106 